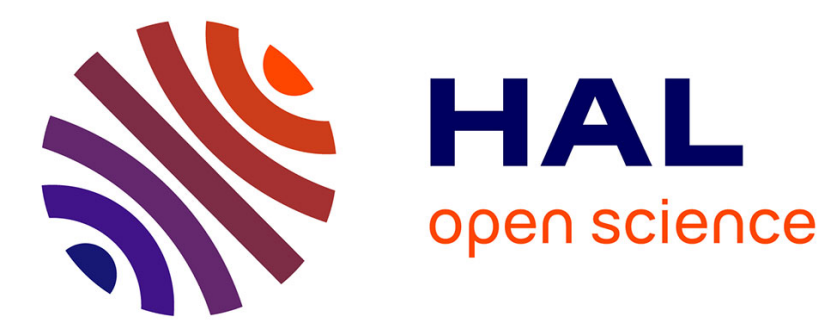

\title{
Low temperature susceptibility of LaNi5 hydrides
}

\author{
J. Palleau, G. Chouteau
}

\section{To cite this version:}

J. Palleau, G. Chouteau. Low temperature susceptibility of LaNi5 hydrides. Journal de Physique Lettres, 1980, 41 (9), pp.227-229. 10.1051/jphyslet:01980004109022700 . jpa-00231766

\section{HAL Id: jpa-00231766 https://hal.science/jpa-00231766}

Submitted on 1 Jan 1980

HAL is a multi-disciplinary open access archive for the deposit and dissemination of scientific research documents, whether they are published or not. The documents may come from teaching and research institutions in France or abroad, or from public or private research centers.
L'archive ouverte pluridisciplinaire HAL, est destinée au dépôt et à la diffusion de documents scientifiques de niveau recherche, publiés ou non, émanant des établissements d'enseignement et de recherche français ou étrangers, des laboratoires publics ou privés. 


\title{
Low temperature susceptibility of $\mathrm{LaNi}_{5}$ hydrides
}

\author{
J. Palleau \\ Centre de Recherches sur les Très Basses Températures, \\ C.N.R.S., B.P. 166X, 38042 Grenoble Cedex, France \\ and G. Chouteau \\ Service National des Champs Intenses, \\ C.N.R.S., B.P. 166X, 38042 Grenoble Cedex, France \\ (Reçu le 12 novembre 1979, révisé le 7 février, accepté le 10 mars 1980)
}

\begin{abstract}
Résumé. - La susceptibilité paramagnétique à $4,2 \mathrm{~K}$ de $\mathrm{LaNi}_{5}$ hydrogéné décroît avec la quantité d'hydrogène absorbé. Nos mesures montrent que la formation de nickel libre se produit lors de la désorption et non lors de l'absorption d'hydrogène.
\end{abstract}

Abstract. - The $4.2 \mathrm{~K}$ paramagnetic susceptibility of $\mathrm{LaNi}_{5}$ hydrides decreases with the hydrogen content. Our measurements show that the formation of nickel particles occurs at the desorption and not at the absorption of hydrogen.

Among the intermetallic compounds, $\mathrm{LaNi}_{5}$ is one of the most interesting because of the very large amount of hydrogen it can absorb. The magnetic properties of the various compounds vary in different ways upon hydriding. Whatever the mechanism of hydrogen absorption can be, for some of them such as $\mathrm{RFe}_{2}[1](\mathrm{R}=\mathrm{Ce}, \mathrm{Y}, \mathrm{Lu}, \mathrm{Sc})$ the hydriding increases the magnetic moment, while in others such as compounds with Co the moment is decreased. Therefore it is of importance to try to understand which mechanism causes the change in magnetic properties after hydrogen absorption.

We have studied the magnetization of the compound $\mathrm{LaNi}_{5}$ at low temperature, in high fields as a function of the amount of absorbed hydrogen. The samples were prepared by fusion in cold levitation crucibles. The starting materials from Johnson-Mattey are $99.99 \%$ wt. purity for $\mathrm{La}$ and 99.999 wt. \% for Ni. To improve homogeneity the samples were repeatedly remelted (three times) and were annealed for 1 day at $1300^{\circ} \mathrm{C}$ and cooled to room temperature by quenching on the cold crucible. All the preparations and the annealings were made under purified argon atmosphere. The metallographic examination showed no other phase and revealed a large grain structure of the compound.

The X-ray diffraction data were obtained on a Phillips X-ray powder diffractometer. The X-ray diagram firstly confirmed the non-existence of a second phase and gives for the lattice constants :

$$
\begin{aligned}
& a=5.017 \pm 0.003 \AA \\
& c=3.983 \pm 0.003 \AA .
\end{aligned}
$$

For magnetic measurements the sample was put in a high purity copper $(99.999 \%$ ) container, sealed under vacuum. Charging with hydrogen is achieved without putting the specimen in contact with atmospheric air. Thus, contamination by water or oxygen is very small. Furthermore the contamination due to the oxygen present in the equivalent dead volume is completely negligible. The quantity of absorbed hydrogen is determined by weighing the sample. The sample mass is of the order of $1.2 \mathrm{~g}$. In the figure 1

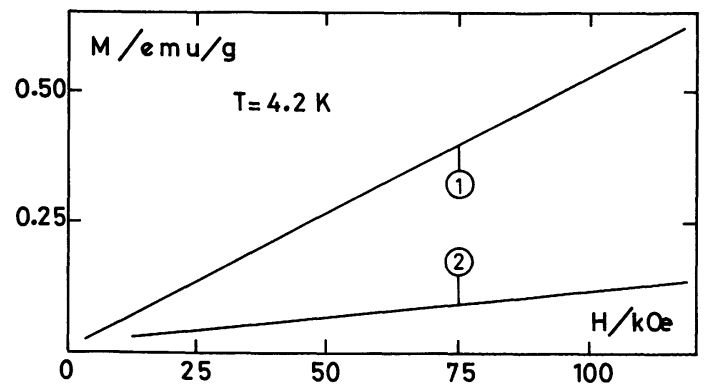

Fig. 1. - Magnetization curves of the fresh (1) and fully hydrided (2) sample. 
we have shown the magnetization curves up to $11.7 \mathrm{~T}$ at $4.2 \mathrm{~K}$ obtained after various charging with hydrogen.

Curve (1) corresponds to pure $\mathrm{LaNi}_{5}$ without hydrogen. No curvature can be observed indicating the absence of particles of pure nickel. We find for the susceptibility :

$$
\chi=5.25 \times 10^{-6} \mathrm{emu} / \mathrm{g}
$$

in good agreement with the recent results of the literature [2]. The complete charge we obtain corresponding to the formula $\mathrm{LaNi}_{5} \mathrm{H}_{6.9}$ gives the curve (2). This shows : i) The magnetization $M$ is no more proportional to the field $H$. An extrapolation of the high field linear part of $M(H)$ to $H=0$ gives an intercept $M_{\mathrm{s}}$ corresponding to the saturation magnetization of a magnetic phase. The thermal variation of $M_{\mathrm{s}}$ suggests that it is due to pure nickel particles. A comparison of $M_{\mathrm{s}}$ to the saturation moment of nickel allows us to evaluate the amount of pure nickel present in the sample. We calculate $0.3 \mathrm{mg}$ (i.e. $\simeq 0.02 \%$ weight of the sample). ii) Considerable decrease in the susceptibility :

$$
\chi=1.05 \times 10^{-6} \mathrm{emu} / \mathrm{g} .
$$

The same behaviour has been observed recently but with a smaller decrease probably due to a smaller hydrogen content [3].

A second set of measurements was performed in the following way :

The sample was fully desorbed and then gradually recharged in pure hydrogen. The quantity of hydrogen absorbed is increased at room temperature by simply increasing the pressure of hydrogen gas, without desorbing the sample. The complete procedure is finally the following : a) Pure $\mathrm{LaNi}_{5}$; $b$ ) Full hydridind; c) Full dehydriding; d) Successive partial hydridings up to full hydrogen absorption.

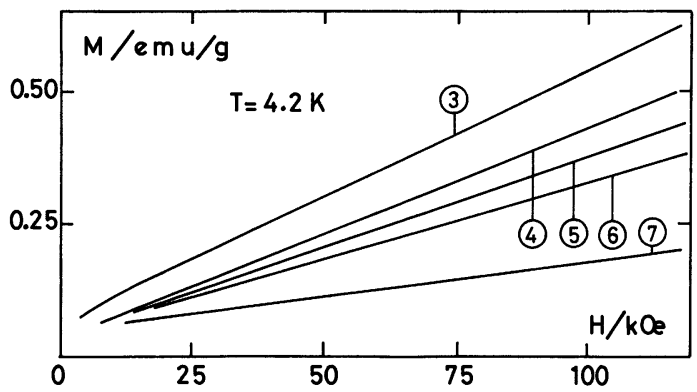

Fig. 2. - Magnetization curves of $\mathrm{LaNi}_{5}$ after complete desorption and partial hydriding : (3) $\mathrm{H} / \mathrm{LaNi}_{5}=0$; (4) $\mathrm{H} / \mathrm{LaNi}_{5}=0.6$; (5) $\mathrm{H} / \mathrm{LaNi}_{5}=1.85 ;$ (6) $\mathrm{H} / \mathrm{LaNi}_{5}=2.68 ;$ (7) $\mathrm{H} / \mathrm{LaNi}_{5}=5.25$.

The results are shown on figure 2 : After complete dehydriding, the magnetization curve is no longer linear (curve (3)) as in the initial state. A rather large amount of pure nickel, $1.3 \mathrm{mg}$, has been formed and furthermore the high field susceptibility is smaller than in the fresh sample : $\chi=4.74 \times 10^{-6} \mathrm{emu} / \mathrm{g}$. However the possibility of formation of $\mathrm{H}_{2}$ traps cannot be completely excluded.

Curves (4) to (7) on figure 2 show the magnetization versus field upon increasing hydriding. No further formation of nickel particles is shown and the susceptibility decreases continuously. As shown on figure 3,

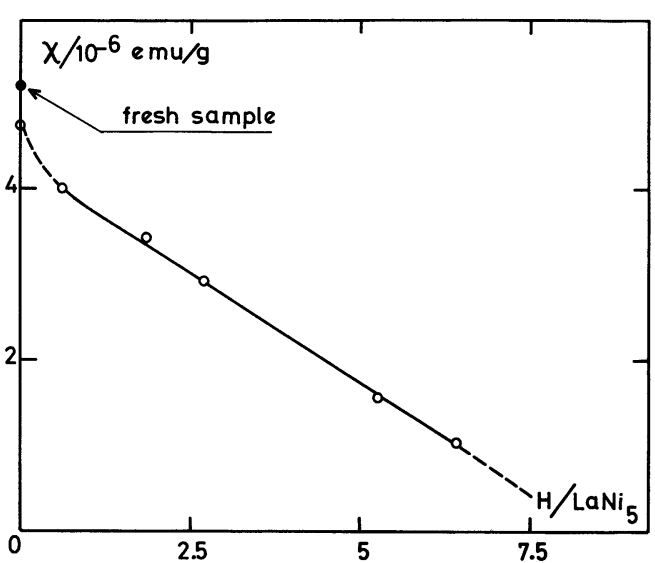

Fig. 3. - Variation of the susceptibility with the ratio $\mathrm{H} / \mathrm{LaNi}_{5}$.

the linear part of the curve $\left(\mathrm{H} / \mathrm{LaNi}_{5}\right)$ extrapolates to zero at $\mathrm{H} / \mathrm{LaNi}_{5} \simeq 8.5$ which is very near the maxima value $\mathrm{H} / \mathrm{LaNi}_{5}=9$ deduced from structural considerations. The results are summarized in the table I.

\begin{tabular}{|c|c|c|}
\hline $\begin{array}{l}\mathrm{H} / \mathrm{LaNi}_{5} \\
\quad 0 \\
6.9\end{array}$ & $\begin{array}{c}\chi\left(10^{-6} \mathrm{emu} / \mathrm{g}\right) \\
5.25 \\
1.05\end{array}$ & $\begin{array}{c}\text { Curve } \\
1 \\
2\end{array}$ \\
\hline $0\left(^{a}\right)$ & 4.74 & 3 \\
\hline 0.60 & 4.0 & 4 \\
\hline 1.85 & 3.43 & 5 \\
\hline 2.68 & 2.91 & 6 \\
\hline 5.25 & 1.77 & 7 \\
\hline
\end{tabular}

Table I.

$\left({ }^{a}\right)$ : After complete desorption.

Our results show that the formation of pure nickel particles is not a consequence of the hydrogen absorption but rather of the desorption. Indeed, the saturation magnetization is strongly increased by complete dehydriding and does not change upon hydriding. Therefore it is difficult to understand how the mechanism proposed in ref. [4] can work. It must be noticed that generally the different authors observe an increase of the amount of pure nickel particles after several cycles. In no way the experimental procedure allow them to conclude whether the formation of these particles occurs during the hydriding or the dehydriding.

The decrease of $\chi$ with the hydrogen content as 
shown in figure 3 can be interpreted as a decrease of the density of states at the Fermi level. This implies, as shown by EPR measurement in hydrided $\mathrm{LaNi}_{5}$, doped with $\mathrm{Gd}$ [5], a charge transfer from $\mathrm{H}$ to $\mathrm{Ni}$ or an equivalent mechanism.
Acknowledgments. - We thank R. Tur for his technical assistance for the magnetization measurements, and Dr. D. Fruchart (R.X. Laboratory) for helpful discussions and critical reading of the manuscript.

\section{References}

[1] Buschow, K. H. J., Solid State Commun. 19 (1976) 421

[2] Buschow, K. H. J., J. Less-Common Metals 51 (1977) 1973.

[3] Schlapbach, L., Stucki, F., Seïler, A., Siegmann, H. C., Int. Conf. on Magnetism, München 1979, to be published in Int. Journal of Magn. and Magn. Materials.
[4] Siegmann, H. C., Schlapbach, L., Brundle, C. R., Phys. Rev. Lett. 40 (1978) 972.

[5] Walsh, W. M. Jr., Rupp, L. W. Jr., Schmidt, P. H., AIP Conf. Proc. 29 (1975) 686. 